\title{
Cyclic Citrullinated Peptide Antibody Measurement
}

National Cancer Institute

\section{Source}

National Cancer Institute. Cyclic Citrullinated Peptide Antibody Measurement. NCI

Thesaurus. Code C96595.

The determination of the amount of cyclic citrullinated peptide antibody present in a sample. 